\title{
GROWTH OF ENDOMYCOPSIS LIPOLYTICA ON HYDROCARBONS
}

\author{
J.N. NIGAM, B.K. LONSANE, K. VADALKAR, H.D. SINGH, \\ J.N. BARUAH AND M.S. IYENGAR \\ Biochemistry Division \\ Regional Research Laboratory, Jorhat-6, Assam, India
}

(Received March 4, 1971)

\begin{abstract}
Ten strains of yeast isolated from the oil fields of Assam in India and identified as Endomycopsis lipolytica were studied. The characteristics of the growth of these ascosporogenous yeast strains on various petroleum fractions and $n$-alkanes are reported for the first time.
\end{abstract}

Ascosporogenous yeasts belonging to genus Endomycopsis were extensively studied by various workers, for their ability to assimilate hydrocarbons E. fibuliger IFO 0103 was tested by TANAKA and FUKUI (1) for growth on decane, octadecane, and mixture of alkanes but with negative results. IIZUKA et al. (2) studied strains from culture collection belonging to E. capsularis and E. fibuliger for assimilation of kerosine. They observed that E. capsularis was not able to utilize kerosine even after 6 days of incubation while $E$. fibuliger gave good growth after 6 days of incubation though the growth was negative after 3 days of incubation. Komagata et al. (3) reported the inability of the strains of $E$. fibuliger and $E$. capsularis from culture collection to assimilate kerosine. The inability of the strains of $E$. fibuliger and $E$. javanensis to utilize alkanes and alkenes was observed by MARKOVETZ and KALLIO (4).

In the beginning of 1970, WICKERHAM et al. (5) isolated from nature an ascosporogenous diploid culture of Candida lipolytica which was identified as E. lipolytica. Recently, from the oil fields of Assam, India, we have isolated 10 strains of yeast which were identified as E. lipolytica. This paper describes, for the first time, the ability of this species of yeast to utilize hydrocarbons.

\section{MATERIALS AND METHODS}

A large number of soil samples collected from the oil fields of Digboi, 
Duliajan, and Sibsagar in Assam were screened by enrichment culture technique for the isolation of hydrocarbon-utilizing yeasts. Composition of the screening and growth media, enrichment culture technique, and methods of isolation, purification, and preservation of yeasts have been reported elsewhere (6). Determination of the morphological and biochemical characteristics of the yeast strains and studies of identification were made according to LODDER and KREGER-VAN RIJ (7).

Hydrocarbon utilization: Biomass yield from gas-oil, diesel oil, and white kerosine by all the strains were studied in the shake flask under condition of culture described in a previous paper $(8)$. The boiling ranges of these petroleum fractions are $250-350^{\circ}$ for gas-oil, $130-334^{\circ}$ for diesel oil, and 150$280^{\circ}$ for white kerosine. Specificity of the strains, Y-15 and Y-16, on different n-alkanes (decane to eicosane) was also determined $(8)$.

Fermentation studies: Cultivation of the strains Y-15 and Y-16 on gasoil was done in a 3-litre fermentor at $10 \%$ gas-oil concentration under condition of culture described before $(6)$. Growth of the organisms was followed by the amount of ammonium hydroxide added to maintain the operational $\mathrm{pH}$.

Crude protein content in the dry cell was estimated by the conventional method of Kjeldahl nitrogen estimation. The procedure used for the preparation of dry cells was described in a previous paper $(6)$.

\section{RESULTS}

Ten yeast cultures capable of utilizing hydrocarbons were isolated from soil and silt samples collected from Assam oil fields and identified as strains of Endomycopsis lipolytica. All these strains produced ascospores within 10 days on gypsum blocks, potato, carrot, and Gorodkowa agar slants. In most cases the fat-splitting test was positive within $24 \mathrm{hr}$ of incubation while the rest gave positive test after $48 \mathrm{hr}$. Some of the differentiating characteristics of the strains are depicted in Table 1.

The data on the comparative utilization of gas-oil, diesel oil, and white kerosine by all the strains for biomass formation are shown in Table 2. In general, the degree of utilization of these substrates for biomass formation is different for all the strains. The strains Y-15 and Y-16 produce the highest biomass yield on all substrates. Comparative utilization of the three petroleum fractions, gas-oil, diesel oil, and white kerosine, by the strains shows a general pattern. Gas-oil promotes highest biomass formation in all the strains except $\mathrm{Y}-14$, followed by diesel oil and white kerosine in that order.

The crude protein content of the dry cells ranges from $38.9 \%$ in Y-9 to the highest value of $61 \%$ in Y-12 (Table 2). Strains Y-15 and Y-16 show clear substrate specificity to members of n-alkane series (Table 3). Strain Y-15 shows profuse growth on hexadecane, octadecane, and decane. Strain Y-16 shows highest biomass formation on decane and, in general, it utilizes 
Table 1. Certain morphological and biochemical characteristics of the strains.

\begin{tabular}{|c|c|c|c|c|c|c|}
\hline \multirow{2}{*}{ Strain } & \multicolumn{2}{|c|}{ Cell size $(\mu)$} & \multicolumn{2}{|c|}{ Pellicle formation, surface growth } & \multirow{2}{*}{$\begin{array}{l}\text { Splitting } \\
\text { of } \\
\text { arbutin }\end{array}$} & \multirow{2}{*}{$\begin{array}{l}\text { Reduction } \\
\text { in litmus } \\
\text { milk }\end{array}$} \\
\hline & Length & Width & 3 days & 1 month & & \\
\hline $\mathrm{Y}-1$ & $10.5-21$ & $3-4.5$ & Ring & Thin pellicle & + & - \\
\hline $\mathrm{Y}-2$ & $9-60$ & $3-4.5$ & Ring & Thin pellicle & - & - \\
\hline$Y-9$ & $7.5-10.5$ & $3-4.5$ & Thin pellicle & Thin pellicle & - & - \\
\hline $\mathrm{Y}-12$ & $4.5-21.0$ & $3-3.5$ & Ring & Ring & - & - \\
\hline $\mathrm{Y}-14$ & $4.5-19.5$ & $3.0-6.0$ & Thin pellicle & Pellicle & + & - \\
\hline$Y-15$ & $6.0-31.5$ & $3.0-4.5$ & Thin pellicle & Pellicle & - & - \\
\hline$Y-16$ & $6.0-60.0$ & $3.0-4.5$ & Loose islet of cells & Thin pellicle & - & + \\
\hline $\mathrm{Y}-20$ & $6.0-24.0$ & $3.0-3.75$ & Pellicle & Pellicle & + & - \\
\hline $\mathrm{Y}-24$ & $6.0-13.5$ & $3.0-4.5$ & Ring & Thin pellicle & - & - \\
\hline Y-31 & $6.0-22.5$ & $3.0-4.5$ & Pellicle & Ring & - & - \\
\hline
\end{tabular}

Table 2. Comparative biomass yield on petroleum fractions.

\begin{tabular}{c|c|c|c|c}
\hline \multirow{2}{*}{ Strain } & $\begin{array}{c}\text { Protein N } \\
(\%)\end{array}$ & \multicolumn{2}{|c|}{ Yield from $100 \mathrm{ml}$ medium $(\mathrm{mg}$ dry cell) } \\
\hline Y-1 & 49.05 & Gas-oil & Diesel oil & White kerosine \\
Y-2 & 40.37 & 182.5 & 92.5 & 77.5 \\
Y-9 & 38.92 & 117.5 & 75.0 & 82.5 \\
Y-12 & 61.06 & 177.5 & 117.5 & 87.5 \\
Y-14 & 36.38 & 107.5 & 107.5 & 87.5 \\
Y-15 & 39.13 & 62.5 & 107.5 & 95.0 \\
Y-16 & 45.1 & 457.5 & 125.0 & 135.0 \\
Y-20 & 36.73 & 235.0 & 132.5 & 122.5 \\
Y-24 & 39.20 & 97.5 & 70.0 & 70.0 \\
Y-31 & 42.5 & 100.0 & 67.5 & 50.0 \\
\hline
\end{tabular}

shorter-chain n-alkanes (decane to dodecane) better than longer ones with the exception of hexadecane and nonadecane.

Cultivation of strains $\mathrm{Y}-15$ and $\mathrm{Y}-16$ on gas-oil in a 3-litre fermentor shows a specific growth rates of $0.16 \mathrm{hr}^{-1}$ and $0.14 \mathrm{hr}^{-1}$ for $\mathrm{Y}-15$ and $\mathrm{Y}-16$, respectively. After $22 \mathrm{hr}$ of cultivation in the fermentor, a total biomass yield of $4.0 \mathrm{~g} \cdot$ litre for $\mathrm{Y}-15$ and $3.1 \mathrm{~g} \cdot$ litre for $\mathrm{Y}-16$ was obtained.

\section{DISCUSSION}

The yeast species $E$. lipolytica is ascosporogenous diploid culture of $C$. lipolytica and was isolated and reported for the first time by WICKERHAM $e t$ 
Table 3. Substrate specificity of strains Y-15 and Y-16 for members of $n$-alkane series.

\begin{tabular}{l|} 
Substrate \\
$\mathrm{n}-\mathrm{C}_{10}$ \\
$\mathrm{n}-\mathrm{C}_{11}$ \\
$\mathrm{n}-\mathrm{C}_{12}$ \\
$\mathrm{n}-\mathrm{C}_{13}$ \\
$\mathrm{n}-\mathrm{C}_{14}$ \\
$\mathrm{n}-\mathrm{C}_{15}$ \\
$\mathrm{n}-\mathrm{C}_{16}$ \\
$\mathrm{n}-\mathrm{C}_{17}$ \\
$\mathrm{n}-\mathrm{C}_{15}$ \\
$\mathrm{n}-\mathrm{C}_{19}$ \\
$\mathrm{n}-\mathrm{C}_{20}$
\end{tabular}

\begin{tabular}{c|c} 
Yield from $100 \mathrm{ml}$ medium $(\mathrm{mg}$ dry cell $)$ \\
\hline Strain Y-15 & Strain Y-16 \\
\hline 496.25 & 313.25 \\
322.5 & 292.65 \\
231.5 & 196.50 \\
241.75 & 139.75 \\
260.50 & 113.5 \\
371.75 & 144.00 \\
822.00 & 195.75 \\
291.25 & 36.25 \\
508.25 & 77.75 \\
183.00 & 278.75 \\
225.5 & 85.50 \\
\hline
\end{tabular}

al. (5) in the beginning of 1970 . The strains of $C$. lipolytica are considered of great potential in hydrocarbon fermentation for the production of single cell proteins, lipids, and other products of economic and industrial importance. Strains of hydrocarbon-utilizing $E$. lipolytica may offer advantages over strains of $C$. lipolytica in hydrocarbon fermentation due to the possibilities of hybridization on selected lines. As WICKERHAM et al. (5) suggested, diploids with higher specific growth rate may improve the economics of the process as the large-celled diploid will offer greater ease in harvesting from fermentation broth. However, surprisingly enough, E. lipolytica has not so far been studied for its hydrocarbon assimilation characteristics.

Out of the 10 strains of E. lipolytica isolated from oil fields of Assam, strains $\mathrm{Y}-15$ and $\mathrm{Y}-16$ are promising for the production of single-cell protein from gas-oil and some of the n-alkanes because of their profuse growth on these substrates.

The ability of these strains to grow moderately well on nonadecane and eicosane which are solid at the temperature of incubation $\left(30^{\circ}\right)$ is interesting. Generally, yeast species show very poor growth on solid alkanes unless a liquid carrier or emulsifier is used $(8-10)$. Exceptionally low affinity of various species of yeast to certain members of n-alkane having odd number of carbons is well-documented $(8)$. This inexplicable phenomenon is also shown by strain Y-16 which utilizes heptadecane very poorly.

\section{REFERENCES}

1) A. TANAKA and S. Fukui, J. Ferm. Technol., 48, 137 (1970). 
2) H. Iizuka, A. Hirano, T. Shilo, Y. Yamamoto and S. Tsuru, Vorträge des Internationalen Symposiums Erdölmikrobiologie, Brno CSSR (1964), p. 163.

3) K. Komagata, T. Nakase and N. Katsuya, J. Gen. Appl. Microbiol., 10, 313 (1964).

4) A.J. Markovetz and R.E. Kallio, J. Bacteriol., 87, 968 (1964).

5) L.J. Wickerham, C.P. Kurtzman and A.I. Herman, Science, 167, 1141 (1970).

6) K. VAdalkar, H.D. Singh, J.N. Baruah and M.S. Iyengar, J. Gen. Appl. Microbiol., 15, 375 (1969).

7) J. Lodder and N.J.W. Kreger-van RiJ, The Yeasts-A Taxonomic Study, 2nd Printing, North Holland Publishing Co., Amsterdam (1957).

8) P.K. Barua, S.D. Bhagat, K.R. Pillai, H.D. Singh, J.N. Baruah and M.S. IYENGAR, Appl. Microbiol., 20, 657 (1970).

9) T.L. Miller and M.J. Johnson, Biotechnol. Bioeng., 8, 549 (1966).

10) K. Yamada and M. Yogo, Agr. Biol. Chem. (Tokyo), 34, 296 (1970). 